\title{
Egy kontrollált Egészségfejlesztő Iskola vizsgálat Hollandiában: hatások a beavatkozás után 1 és 2 évvel
}

\author{
A Controlled Health Promoting School Study in the Netherlands: \\ Effects After 1 and 2 Years of Intervention
}

Ismertető: $\quad$ Maczali Katalin $\square$

Állami Egészségügyi Ellátó Központ

Szerzők: Busch V, De Leeuw JR, Zuithoff NP, Van Yperen TA, Schrijvers AJ.

Megjelenés: Health Promotion Practice. July 2015 Vol. 16, No. (4) 592-600.

DOI: $10.1177 / 1524839914566272$

Beküldve: 2017.09.12.

doi: 10.24365/ef.v58i3.185

Kulcsszavak: viselkedésváltozás; iskolai egészségfejlesztés; Egészségfejlesztő Iskola

\section{ÖSSZEFOGLALÁS}

Az 1990-es években a WHO kimondta, az iskola a legoptimálisabb hely a gyermekek egészségfejlesztéséhez. Ebben a megközelítésben az iskolákat, mint a gyermekek egészségének, oktatásának és társas fejlődésének színtereként, egy közösségi találkozási pontként látjuk.

Az egészségtelen magatartási szokások többsége gyakran a fiatal felnőttkorban alakul ki. A kutatás során 4 holland, két intervencióba bevont középiskolát és két kontroll iskolát követtek nyomon a szakértők, hogy kielemezzék az egészségmagatartást, a testtömegindexet (BMI) és a pszicho-szociális problémákat célzó intervenció hatásait 1 és 2 év után.

Az eredményeket önbevallásos kérdőívekkel mérték és kevert módszeres regressziós analízissel vizsgálták. Kérdőívvel gyűjtöttek adatot az alkohol és marihuána használatról, a dohányzásról, a táplálkozási szokásokról, a mozgásról, a heti tv nézési órákról, az internet használatról, a szocio-demográfiai tényezőkről, és a BMI-ről.

A kvalitatív adatgyűjtés 28 strukturált interjúból állt, melyeket az intervenciós iskolák tanáraival készítettek, hogy feltérképezhessék az iskoláikban a program megvalósításának sikerességét.
A 2010-2011-es iskolai év során, a korábbi holland próbatanulmányok után, az intervenciót átültették két holland középiskolába (intervenciós iskola " $\mathrm{A}$ ” és „ $\mathrm{B}^{\prime)}$ ), illetve két iskolát kontrollcsoportként vizsgáltak.

$A z$ „A $A$ " iskola elsődlegesen a gyakoribb testmozgást akarta népszerűsíteni és csökkenteni a képernyő előtt töltött órák számát, elősegíteni az egészséges testsúly elérését és megtartását, az egészséges étkezést, csökkenteni és megelőzni a dohányzást. 1 év után a BMI és a túlzott internethasználat is csökkent, de a többi faktor nem változott a kontroll diákokéhoz képest.

$A$ „ $B$ ” iskolában 1 és 2 év után sem változott a kitúzött cél, a jobb étkezés és a több mozgás; bár az alkohol használat adatai jobbak voltak a kontroll iskoláéhoz képest.

$\mathrm{Az}$ "A" iskola sikeresen megvalósította a kutatás minden alapegységét - mint a dohányzásmentes iskolai terület kialakítása, aktív szülői és közösségi részvétel elérése az iskolai programokon, zéró tolerancia az iskolai zaklatásokra, illetve egészségfejlesztési programok szervezése, míg a „B" iskola csak az egészséges iskolai szabályozásokat vezette be és egy „egészséges iskola” koordinátort nevezett ki. Két év után, az " $A$ ” intervenciós iskola szignifikáns 
fejlődést mutatott: a testtömegindex és a túlzott monitor használat is tovább csökkent. A másik intervenciós iskolában az elsődleges célok nem teljesültek. Ezek az eredmények azt mutatják, hogy személyre szabottabb intervenciókra van szükség.
A személyre szabott megközelítés során valószínübb egy olyan intervenció megvalósulása, amely releváns az adott iskolára nézve, hiszen csak azokra a témákra koncentrál, amely elsődlegesen fontos az iskolának.

\section{KULCSÜZENET A SZAKEMBEREK SZÁMÁRA}

A kutatás során áttekintették a szakemberek egy kontrollált után-követéses vizsgálatban az intervenciók hatásait a diákok egészségére és egészségmagatartására, meghatározták a projekt megvalósíthatóságát az átlagos holland gimnáziumokra vonatkozóan, és megvizsgálták a kevert módszeres megközelítést. A projekt sikeresen magvalósult és szignifikáns fejlődést mutatott a diákok pszicho-szociális egészségében, csökkentette az alkohol használatot, a dohányzást és a zaklatásokat. 